\title{
KARAKTERISTIK AIR TERJUN SEBAGAI POTENSI WISATA ALAM DI KECAMATAN SUKASADA
}

\author{
Fahyumi Rahman ${ }^{1}$, I Putu Ananda Citra ${ }^{2 *}$
}

Program Studi Pendidikan Geografi, Universitas Pendidikan Ganesha, Indonesia

\section{A R T I C L E I N F O \\ Article history: \\ Received 10 agustus 2018 \\ Received in revised form \\ 17 November 2018 \\ Accepted 12 November \\ 2018 \\ Available online 30 \\ November 2018}

\section{Kata Kunci:}

Karakteristik

Potensi Wisata

Air Terjun

Keywords:

Characteristics,

Tourism Potential,

INatarfall

\begin{abstract}
A B S T R A K
Penelitian ini dilaksanakan di Kecamatan Sukasada, dengan tujuan yaitu: (1) Mendeskripsikan karakteristik air terjun di Kecamatan Sukasada, (2) Menganalisis tingkat potensi wisata alam air terjun di Kecamatan Sukasada. Rancangan penelitian menggunakan rancangan deskriptif dengan analisis keruangan. Penelitian ini menggunakan metode survey yang meliputi observasi pengukuran morfometri air terjun, wawancara tidak terstruktur dan dokumentasi. Metode analisis digunakan adalah analisis deskriptif dan deskriptif kualitatif. Hasil penelitian menunjukkan: (1) Terdapat tujuh karakteristik air terjun diantaranya tipe cascade, tipe cataract, tipe chute, tipe slide, tipe birai menggantung, tipe parallel, tipe waterfall. Air terjun tipe cascade adalah paling banyak terdapat di Kecamatan Sukasada, dan yang paling sedikit adalah tipe cataract dan chute. (2) Air terjun yang memiliki tingkat potensi tinggi hanya sekitar 25,8 $\%$.Tingkat potensi wisata kategori sedang terdapat 32,25 \%, belum maksimalnya sarana akomodasi dan atraksi wisata yang belum bervariasi. Sedangkan untuk kategori rendah adalah yang terbanyak yaitu sekitar $41,93 \%$ hal tersebut disebabkan oleh beberapa faktor yang dominan mempengaruhi adalah belum terbukanya akses menuju air terjun, atraksi dan akomodasi yang belum memadai, serta pengelolaan objek wisata yang belum maksimal.
\end{abstract}

\section{A B S T R A C T}

This research was conducted in Sukasada sub-district, with the purpose of: (1) describe waterfalls characteristics in Sukasada sub-district, (2) to analyze the natural tourism potential of waterfalls in Sukasada sub-district. The design of the research used descriptive design with spatial analysis. This research used survey method which was including observation of waterfall morphometry measurement, unstructured interview and documentation. Then, the method of analysis used were descriptive and descriptive qualitative analysis. The results showed: (1) There are seven characteristics of waterfall in Sukasada sub-district including cascade type, cataract type, chute type, slide type, over hanging ledge falls type, parallel type, and waterfall type. The waterfall of cascade type is the mostly found in Sukasada sub-district and the least is the type of cataract and chute which is. (2) There are only $25.8 \%$ of Waterfalls in sukasada sub district which have high potential level of tourism, Furthermore, the level of medium category tourism potential is only $32.25 \%$ of the overall waterfall. Since, it has minimum accommodation and tourist attractions that have not varied. On the other hand, the low category is only $41.93 \%$. It is caused by several factors especially the poor accessibility to waterfall, unvaried attraction and minimum accommodation, and also management of tourist object which does not maximal yet.

\footnotetext{
* Corresponding author.

E-mail addresses: fahyumi29rahman@gmail.com, ananda.citra@undiksha.ac.id
} 


\section{Pendahuluan}

Prospek pariwisata ke depan bagi Negara Indonesia sangat menjanjikan bahkan memberikan peluang besar, terutama apabila menyimak angka-angka perkiraan jumlah wisatawan internasional (inbound tourism) berdasarkan perkiraan WTO yakni 1,046 milyar orang di tahun 2010 dan 1,602 milyar orang pada tahun 2020, diantaranya masing-masing 231 juta dan 438 juta orang berada di kawasan Asia Timur dan Pasifik, akan mampu menciptakan pendapatan dunia sebesar USD 2 triliun pada tahun 2020 (Sutrisno, 2016). Berdasarkan angka perkiraan tersebut maka, para pelaku pariwisata Indonesia perlu melakukan perencanaan yang matang dan terarah untuk mengoptimalkan peluang tersebut. Perkembangan pariwisata seiring dengan kemajuan teknologi dan peningkatan populasi akan mampu meningkatkan kunjungan wisatawan. Untuk menunjang sektor pariwisata di Indonesia sangat berkaitan dengan data sebaran objek pariwisata di setiap wilayah Indonesia yang memiliki variasi keruangan dan karakteristik wilayah yang berbeda. Setiap wilayah di Indonesia jika ditinjau dari aspek keruangan dan kewilayahan memiliki karakteristik yang bervariasi baik dari segi fisik wilayah, budaya dan potensi pariwisata.

Perbedaan karakteristik dan potensi wilayah ini yang mendorong adanya suatu sektor unggulan dalam mengembangkan potensi yang ada pada suatu wilayah. Hal ini senada dengan apa yang diungkapkan oleh Suditha I Nyoman dan Astawa (2013) bahwasanya dalam kajian geografi regional, disamping upaya mengkaji dan memahami karakteristik wilayah, juga sekaligus mengkaji potensi-potensi dan permasalahan utamanya serta memprediksi terhadap perubahan dan perkembangannya pada masa yang akan datang. Kendati demikian elemen dari sumber daya alam seperti air, pegunungan, pantai, bentang alam dan sebagainya, tidak akan menjadi sumber daya yang berguna bagi pariwisata kecuali semua elemen tersebut dapat memuaskan dan memenuhi kebutuhan manusia, sehingga diperlukan intervensi manusia untuk mengubahnya menjadi bermanfaat untuk wisata alam maupun hal lainnya di wilayah tersebut (Pitana, I G dan Diarta, 2009).

Salah satu daerah di Indonesia yang memiliki keberagaman objek pariwisata adalah Provinsi Bali. Pulau Bali memiliki Objek Daya Tarik Wisata (ODTW) yang bervariasi mulai dari wisata budaya dan wisata alam yang menyajikan pemandangan indah dan khas sehingga dapat menarik wisatawan lokal maupun mancanegara untuk mengunjungi daerah Bali. Keberadaan objek wisata yang tersebar di beberapa daerah di wilayah Bali, tidak diimbangi dengan pemerataan kunjungan wisatawan yang sebagian besar wisatawan hanya berkunjung pada wilayah Bali Selatan. Hal ini dikarenakan pembangunan yang terfokus di wilayah Bali Selatan dan keterjangkauan lokasi objek wisata dari wilayah selatan yang mempengaruhi kunjungan pariwisata ke setiap daerah. Sehingga objek wisata yang terdapat di daerah lain di wilayah Provinsi Bali masih kurang dikunjungi wisatawan, seperti objek wisata yang terdapat di wilayah Bali Utara. Ketimpangan pembangunan pariwisata di Bali akan berdampak pada tidak optimalnya potensi di setiap daerah dan keberlanjutan eksistensi wisata yang ada di Bali. Sedangkan perbedaan objek wisata yang terdapat di setiap daerah memiliki kekhasan dan potensi yang berbeda-beda, sehingga faktor pendorong minat kunjungan wisatawan juga bervariasi sesuai dengan kenampakan potensi daerah dan pemerataan pembangunan objek wisata daerah di Bali yang menyeluruh.

Daerah Buleleng memiliki karakteristik topografi yang kompleks, mulai dari daerah pesisir yang merupakan daerah dengan garis pantai terpanjang di Provinsi Bali, serta daerah perbukitan yang membentang pada wilayah bagian selatan di Buleleng. Jika dilihat dari bentang alamnya topografi Kabupaten Buleleng didominasi oleh daerah perbukitan yang memanjang 
sehingga di Kabupaten Buleleng banyak dijumpai objek wisata air terjun yang terdapat hampir disetiap aliran sungai permanen pada wilayah ketinggian tertentu. Distribusi keberadaan air terjun tidak memiliki keunikan dan pengelompokan sebaran pada daerah-daerah tertentu di Kabupaten Buleleng yang salah satu daerah yang memiliki potensi wisata air terjun yaitu di Kecamatan Sukasada. Namun problematika pembangunan potensi wisata yang berada di wilayah Bali Utara masih belum dioptimalkan.

Kecamatan Sukasada terletak di Kabupaten Buleleng, Provinsi Bali yang terdiri dari 15 desa, dengan luas wilayah 172,93 km2. jumlah penduduk 71. 459 jiwa. Kecamatan Sukasada terletak pada kawasan Middle land hingga Up land di Kabupaten Buleleng yang sebagian wilayahnya adalah kawasan hutan dan perkebunan. Kondisi toporgrafi Kecamatan Sukasada yang merupakan perbukitan dan banyak terdapat aliran sungai, menjadikan kawasan Sukasada banyak tersebar air terjun. Keadaan tersebut dibuktikan dengan adanya pengelompokan sebaran air terjun di kawasan Desa Gitgit dan Desa Sambangan yang banyak dikunjungi wisatawan untuk kategori wisata alam di Kecamatan Sukasada. Sesuai observasi awal yang dilakukan peneliti bahwa terdapat beberapa desa yang terdapat pengelompokan air terjun yang sudah dikelola dengan baik yang diantaranya Desa Gitgit, Sambangan, Ambengan dan Wanagiri. Kendati demikian desa-desa lainnya di Kecamatan Sukasada juga memiliki potensi keberadaan air terjun namun masih belum dikenal luas oleh masyarakat. Selain itu lokasi relatif Kecamatan Sukasada yang strategis yaitu dekat dengan pusat Kota Singaraja dan wilayahnya merupakan jalur penghubung antara Bali Utara dan Bali Selatan. Hal tersebut merupakan peluang untuk dapat mengembangkan potensi yang terdapat di wilayah yang memiliki akses strategis, yang salah satunya adalah potensi wisata alam air terjun di Kecamatan Sukasada.

Air terjun di Kecamatan Sukasada merupakan aset wisata alam daerah yang khas dan banyak tersebar di wilayah Bali Utara. Distribusi air terjun yang berada di kawasan Sukasada merupakan inventaris wisata alam yang harus di data dan dikembangkan menjadi pariwisata unggulan. Selain itu, beberapa air terjun di wilayah Kecamatan Sukasada, juga masih belum merata diketahui dan dikembangkan sehingga dalam kegiatan eksplorasi terkait keberadaan air terjun dilakukan kajian terkait dengan potensi dan karakteristik fisik air terjun, sehingga akan nampak perbedaan dan potensi wisata alam air terjun yang dimiliki oleh Kabupaten Buleleng. Pendataan dan pemetaan dengan melakukan penjajakan (Exploration) pada daerah yang memiliki potensi adanya air terjun seperti pada daerah perbukitan dan lereng curam yang dilalui aliran sungai di Kecamatan Sukasada. Penelitian ini memiliki tujuan mendeskripsikan karakteristik fisik air terjun yang terdapat di Kecamatan Sukasada dan menganalisis tingkat potensi wisata air terjun di Kecamatan Sukasada.

\section{Metode}

Rancangan yang digunakan pada penelitian ini adalah deskriptif dengan analisis keruangan. Menurut Tika (2005) penelitian deskriptif merupakan pegungkapan suatu masalah atau keadaan sebagaimana adanya dan mengungkapkan fakta-fakta yang ada, walaupun kadangkadang diberikan interpretasi atau analisis. Rancangan ini berkaitan dengan tujuan penelitian yaitu untuk mendata dan mendeskripsikan karakteristik fisik dan tingkat potensi wisata air terjun di Kecamatan Sukasada.

Berdasarkan metodenya, penelitian ini merupakan penelitian survei. Survei merupakan suatu penyelidikan yang dilakukan untuk memperoleh fakta-fakta dari gejala-gejala yang ada dan mencari keterangan secara faktual (Yunus, 2016). penelitian ini membutuhkan data primer dan data sekunder. Data primer dalam penelitian ini merupakan data hasil survey yang 
mengukur morfometri air terjun dan variabel potensi wisata air terjun yang dapat dilihat pada Tabel 1.

Tabel 1. Data primer Penelitian

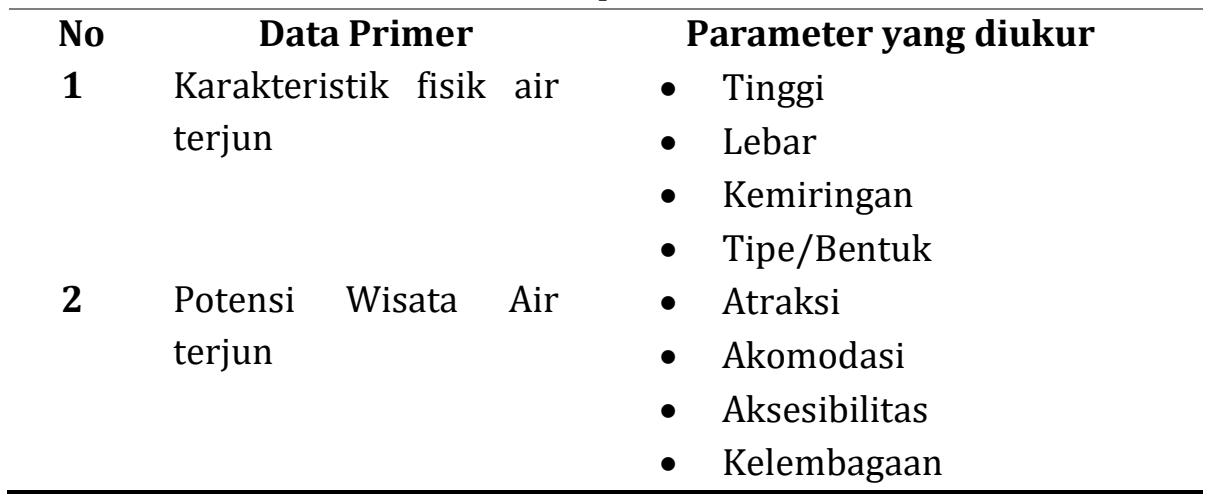

Sedangkan data sekunder dalam penelitian ini merupakan data terkait dengan Fisiografis dan demografis wilayah Kecamatan Sukasada.

Metode analisis yang digunakan dalam penelitian ini adalah analisis deskriptif. Teknik analisis untuk rumusan masalah yang pertama yaitu dilakukan dengan menggunakan analisis deskriptif dengan memanfaatkan data dari hasil survei lapangan dan dikorelasikan melalui penggolongan tipe air terjun menurut glaubitz. Sedangkan Teknik analisis yang digunakan untuk rumusan masalah yang kedua adalah analisis deskriptif kualitatif. Teknik tersebut dilakukan dengan menganalisis data yang diperoleh dari observasi dan wawancara terkait variabel potensi wisata air terjun dan kemudian dilakukan penskoran data untuk memperoleh data tingkat potensi wisata air terjun

\section{Hasil dan pembahasan}

\subsection{Karakteristik Air Terjun di Kecamatan Sukasada}

Lobeck (1981) menyatakan bahwa Air terjun dan jeram- jeram adalah kriteria dan ukuran sungai peringkat muda. Bentuk ini dibagi menjadi dua jenis : Pertama adalah bentuk air terjun yang telah melalui pengikisan sungai dan menunjukan bahwa sungai belum dapat menunjukan sebuah cekung yang bertingkat, dan kedua ialah bentuk bentuk yang terjadi disebabkan oleh gangguan atau kuasa luar dalam proses pembentukan sungai. Secara umum air terjun memiliki variasi tipe dan bentuk serta kenampakan yang berbeda beda di setiap wilayah. (Marjohan, 2008) menggolongkan air terjun berdasarkan kenampakan fisiknya yaitu sebagai berikut:

1) Cascade merupakan air terjun dengan sekala kecil yang umum digunakan untuk menjelaskan bagian dari air terjun.

2) Cataract merupakan air terjun yang mempunyai ketinggian lebih dari 30 meter dan mempunyai kekuatan aliran air yang kuat

3) Chute merupakan air terjun yang berbentuk sempit dan mempunyai kekuatan besar umumnya berada diantara dua buah batuan besar atau pada dinding jurang dan lebar dinding air terjun yang sempit yaitu kurang dari 2 meter

4) Slide (luncur) merupakan air terjun yang terbentuk karena aliran sungai yang mengalir mengikuti kemiringan permukaan dinding tebing, dengan kemiringan tebing kurang dari 70 derajat. 
5) Over Hanging ledge falls (birai menggantung), tipe air terjun yang pancaran airnya menonjol keluar dari tebing air terjun/ air tidak menyentuh dinding air terjun.

6) Parallel tipe ini terbentuk dari dua buah air terjun yang letaknya berdampingan satu sama lain.

7) Waterfall, yaitu bagian dari sungai yang jatuh secara vertikal ke suatu tempat dan umumnya lebarnya lebih dari dua meter, tipe waterfall ini merupakan tipe umum yang tidak masuk kategori air terjun sebelumnya.

Karakteristik air terjun tersebar di wilayah Kecamatan Sukasada memiliki variasi bentuk yang beragam. Kondisi geografis Kecamatan Sukasada yang didominasi oleh wilayah perbukitan dan memiliki banyak aliran sungai permanen mengakibatkan wilayah Sukasada banyak terdapat Air terjun. Kenampakan fisik air terjun yang bervariasi dan memiliki eksotika yang khas merupakan daya tarik untuk wisatawan yang menyukai panorama alam dan olahraga ekstream. Kecamatan Sukasada memiliki 31 air terjun yang memiliki perbedaan ukuran dan bentuk yang bervariasi. Distribusi air terjun di daerah penelitian terdapat beberapa pengelompokan air terjun di Desa Ambengan sebanyak 2 air terjun, Desa Gitgit sebanyak 6 air terjun, Desa Padang Bulia sebanyak 1 air terjun, Desa Pegayaman sebanyak 2 air terjun, Desa Sambangan sebanyak 7 air terjun, dan Desa Wanagiri sebanyak 13 air terjun.

Karakteristik air terjun yang tersebar di Kecamatan Sukasada dikelompokan menjadi tujuh tipe air terjun menurut teori (Lubis, 2011) tentang penggolongan air terjun menurut kenampakan fisiknya. Untuk lebih jelasnya dapat dilihat pada Tabel 2. Karakteristik Tipe Air Terjun di Kecamatan Sukasada.

Tabel 2. Karakteristik tipe air terjun di Kecamatan Sukasada

\begin{tabular}{|c|c|c|c|c|c|c|c|}
\hline No & Air Terjun & $\begin{array}{l}\text { Tinggi } \\
\text { (meter) }\end{array}$ & $\begin{array}{l}\text { Lebar } \\
\text { (meter) }\end{array}$ & $\begin{array}{l}\text { Kemiringan } \\
\text { Tebing }\end{array}$ & $\begin{array}{l}\text { Ketinggian } \\
\text { (Mdpl) }\end{array}$ & Lokasi & $\begin{array}{c}\text { Tipe/ } \\
\text { Bentuk }\end{array}$ \\
\hline 1 & Bertingkat & $\begin{array}{l}\text { 12,3 } \\
\text { (Sedang) }\end{array}$ & $\begin{array}{l}3,1 \\
\text { (Lebar) }\end{array}$ & $\begin{array}{l}>70^{\circ} \\
\text { (Vertikal) }\end{array}$ & 723 & Desa Gitgit & Cascade \\
\hline 2 & Jembong & $\begin{array}{l}5,9 \\
\text { (Rendah) }\end{array}$ & $\begin{array}{l}4,3 \\
\text { (Lebar) }\end{array}$ & $\begin{array}{l}>70^{\circ} \\
\text { (Vertikal) }\end{array}$ & 475.97 & Desa Ambengan & Cascade \\
\hline 3 & Indah & $\begin{array}{l}7,1 \\
\text { (Rendah) }\end{array}$ & $\begin{array}{l}2,8 \\
\text { (Sedang) }\end{array}$ & $\begin{array}{l}>70^{\circ} \\
\text { (Vertikal) }\end{array}$ & 1080.64 & Desa Wanagiri & Cascade \\
\hline 4 & Banyumala & $\begin{array}{l}24,3 \\
\text { (Sedang) }\end{array}$ & $\begin{array}{l}9,7 \\
\text { (Lebar) }\end{array}$ & $\begin{array}{l}>70^{\circ} \\
\text { (Vertikal) }\end{array}$ & 1083.04 & Desa Wanagiri & Cascade \\
\hline 5 & Berundak & $\begin{array}{l}14,2 \\
\text { (Sedang) }\end{array}$ & $\begin{array}{l}2,4 \\
\text { (Sedang) }\end{array}$ & $\begin{array}{l}>70^{\circ} \\
\text { (Vertikal) }\end{array}$ & 1025 & Desa Wanagiri & Cascade \\
\hline 6 & Merebo & $\begin{array}{l}26,6 \\
\text { (Sedang) }\end{array}$ & $\begin{array}{l}3,1 \\
\text { (Lebar) }\end{array}$ & $\begin{array}{l}>70^{\circ} \\
\text { (Vertikal) }\end{array}$ & 454 & $\begin{array}{l}\text { Desa } \\
\text { Pegayaman }\end{array}$ & Cascade \\
\hline 7 & $\begin{array}{l}\text { Banyuwana } \\
\text { Amerta } 1\end{array}$ & $\begin{array}{l}6,0 \\
\text { (Rendah) }\end{array}$ & $\begin{array}{l}10,3 \\
\text { (Lebar) }\end{array}$ & $\begin{array}{l}>70^{\circ} \\
\text { (Vertikal) }\end{array}$ & 905 & Desa Wanagiri & Cascade \\
\hline 8 & Gunung Sari & $\begin{array}{l}28,5 \\
\text { (Sedang) }\end{array}$ & $\begin{array}{l}4,1 \\
\text { (Lebar) }\end{array}$ & $\begin{array}{l}>70^{\circ} \\
\text { (Vertikal) }\end{array}$ & 550 & Desa Ambengan & Cascade \\
\hline 9 & Besar & $\begin{array}{l}30,1 \\
\text { (Tinggi) }\end{array}$ & $\begin{array}{l}3,1 \\
\text { (Lebar) }\end{array}$ & $\begin{array}{l}>70^{\circ} \\
\text { (Vertikal) }\end{array}$ & 1087 & Desa Wanagiri & Cataract \\
\hline 10 & Neru & $\begin{array}{l}30,9 \\
\text { (Tinggi) }\end{array}$ & $\begin{array}{l}3,6 \\
\text { (Lebar) }\end{array}$ & $\begin{array}{l}>70^{\circ} \\
\text { (Vertikal) }\end{array}$ & 984 & Desa Wanagiri & Cataract \\
\hline 11 & $\begin{array}{l}\text { Tembok } \\
\text { barak }\end{array}$ & $\begin{array}{l}5,2 \\
\text { (Rendah) }\end{array}$ & $\begin{array}{l}2 \\
\text { (Sempit) }\end{array}$ & $\begin{array}{l}>70^{\circ} \\
\text { (Vertikal) }\end{array}$ & 114 & $\begin{array}{l}\text { Desa } \\
\text { Sambangan }\end{array}$ & Chute \\
\hline 12 & Tebing & 21,2 & 0,9 & $>70^{\circ}$ & 1003 & Desa Wanagiri & Chute \\
\hline
\end{tabular}




\begin{tabular}{|c|c|c|c|c|c|c|}
\hline & (Sedang) & (Sempit) & (Vertikal) & & & \\
\hline 13 Canging & $\begin{array}{l}4,5 \\
\text { (Rendah) }\end{array}$ & $\begin{array}{l}3,5 \\
\text { (Lebar) }\end{array}$ & $\begin{array}{l}<70^{\circ} \\
\text { (Miring) }\end{array}$ & 768 & $\begin{array}{l}\text { Desa Sambanga } \\
\mathrm{n}\end{array}$ & Slide \\
\hline 14 Dedari & $\begin{array}{l}12,9 \\
\text { (Sedang) }\end{array}$ & $\begin{array}{l}2,2 \\
\text { (Sedang) }\end{array}$ & $\begin{array}{l}<70^{\circ} \\
\text { (Miring) }\end{array}$ & 819.88 & $\begin{array}{l}\text { Desa } \\
\text { Sambangan }\end{array}$ & Slide \\
\hline 15 Tunggal & $\begin{array}{l}11,1 \\
\text { (Sedang) }\end{array}$ & $\begin{array}{l}1,3 \\
\text { (Sempit) }\end{array}$ & $\begin{array}{l}<70^{\circ} \\
\text { (Miring) }\end{array}$ & 756 & Desa Gitgit & Slide \\
\hline 16 No name 1 & $\begin{array}{l}18 \\
\text { (Sedang) }\end{array}$ & $\begin{array}{l}1,2 \\
\text { (Sempit) }\end{array}$ & $\begin{array}{l}<70^{\circ} \\
\text { (Miring) }\end{array}$ & 835 & Desa Gitgit & Slide \\
\hline 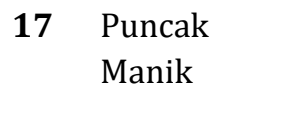 & $\begin{array}{l}\text { 10,3 } \\
\text { (Sedang) }\end{array}$ & $\begin{array}{l}7,3 \\
\text { (Lebar) }\end{array}$ & $\begin{array}{l}>70^{\circ} \\
\text { (Vertikal) }\end{array}$ & 1046.51 & Desa Gitgit & $\begin{array}{l}\text { Birai } \\
\text { Mengga } \\
\text { ntung }\end{array}$ \\
\hline 18 Cinta & $\begin{array}{l}\text { 6,2 } \\
\text { (Rendah) }\end{array}$ & $\begin{array}{l}0,8 \\
\text { (Sempit) }\end{array}$ & $\begin{array}{l}>70^{\circ} \\
\text { (Vertikal) }\end{array}$ & 1192 & Desa Gitgit & $\begin{array}{l}\text { Birai } \\
\text { Mengga } \\
\text { ntung }\end{array}$ \\
\hline $\begin{array}{l}19 \text { Padang } \\
\text { Bulia }\end{array}$ & $\begin{array}{l}21,9 \\
\text { (Sedang) }\end{array}$ & $\begin{array}{l}7, \quad 2 \\
\text { (Lebar) }\end{array}$ & $\begin{array}{l}>70^{\circ} \\
\text { (Vertikal) }\end{array}$ & 160 & Desa Gitgit & $\begin{array}{l}\text { Birai } \\
\text { Mengga } \\
\text { ntung }\end{array}$ \\
\hline No name 2 & $\begin{array}{l}10,2 \\
\text { (Sedang) }\end{array}$ & $\begin{array}{l}1,7 \\
\text { (Sempit) }\end{array}$ & $\begin{array}{l}>70^{\circ} \\
\text { (Vertikal) }\end{array}$ & 863 & Desa Gitgit & $\begin{array}{l}\text { Birai } \\
\text { Mengga } \\
\text { ntung }\end{array}$ \\
\hline 21 Kroya & $\begin{array}{l}10 \\
\text { (Rendah) }\end{array}$ & 4 (Lebar) & $\begin{array}{l}>70^{\circ} \\
\text { (Vertikal) }\end{array}$ & 264,25 & $\begin{array}{l}\text { Desa } \\
\text { Sambangan }\end{array}$ & Parallel \\
\hline Kembar & $\begin{array}{l}9 \\
\text { (Rendah) }\end{array}$ & 4 (Lebar) & $\begin{array}{l}<70^{\circ} \\
\text { (Miring) }\end{array}$ & 264.49 & $\begin{array}{l}\text { Desa } \\
\text { Sambangan }\end{array}$ & Parallel \\
\hline 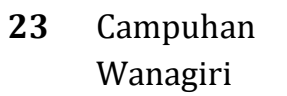 & $\begin{array}{l}6,2 \\
\text { (Rendah) }\end{array}$ & $\begin{array}{l}1,6 \\
\text { (Sempit) }\end{array}$ & $\begin{array}{l}<70^{\circ} \\
\text { (Miring) }\end{array}$ & 910,49 & Desa Wanagiri & Parallel \\
\hline Twin Gitgit & $\begin{array}{l}12 \\
\text { (Sedang) }\end{array}$ & $\begin{array}{l}3,3 \\
\text { (Lebar) }\end{array}$ & $\begin{array}{l}>70^{\circ} \\
\text { (Vertikal) }\end{array}$ & 762,7 & Desa Gitgit & Parallel \\
\hline 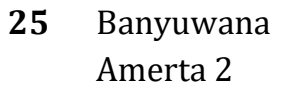 & $\begin{array}{l}7 \\
\text { (Rendah) }\end{array}$ & $\begin{array}{l}6,2 \\
\text { (Lebar) }\end{array}$ & $\begin{array}{l}>70^{\circ} \\
\text { (Vertikal) }\end{array}$ & 888 & Desa Wanagiri & Parallel \\
\hline 26 Aling aling & $\begin{array}{l}22 \\
\text { (Sedang) }\end{array}$ & 3 (Lebar) & $\begin{array}{l}>70^{\circ} \\
\text { (Vertikal) }\end{array}$ & 272 & $\begin{array}{l}\text { Desa } \\
\text { Sambangan }\end{array}$ & $\begin{array}{l}\text { Waterfal } \\
l\end{array}$ \\
\hline Pucuk & $\begin{array}{l}8 \\
\text { (Rendah) }\end{array}$ & 3 (Lebar) & $\begin{array}{l}>70^{\circ} \\
\text { (Vertikal) }\end{array}$ & 268 & $\begin{array}{l}\text { Desa } \\
\text { Sambangan }\end{array}$ & $\begin{array}{l}\text { Waterfal } \\
l\end{array}$ \\
\hline 28 Cemara & $\begin{array}{l}17,6 \\
\text { (Sedang) }\end{array}$ & $\begin{array}{l}7,3 \\
\text { (Lebar) }\end{array}$ & $\begin{array}{l}>70^{\circ} \\
\text { (Vertikal) }\end{array}$ & 887,17 & $\begin{array}{l}\text { Desa } \\
\text { Sambangan }\end{array}$ & $\begin{array}{l}\text { Waterfal } \\
\text { l }\end{array}$ \\
\hline Gitgit & $\begin{array}{l}22 \\
\text { (Sedang) }\end{array}$ & $\begin{array}{l}4,8 \\
\text { (Lebar) }\end{array}$ & $\begin{array}{l}>70^{\circ} \\
\text { (Vertikal) }\end{array}$ & 568.98 & Desa Gitgit & $\begin{array}{l}\text { Waterfal } \\
l\end{array}$ \\
\hline Cinon & $\begin{array}{l}14,6 \\
\text { (Sedang) }\end{array}$ & $\begin{array}{l}3,1 \\
\text { (Lebar) }\end{array}$ & $\begin{array}{l}>70^{\circ} \\
\text { (Vertikal) }\end{array}$ & 426 & $\begin{array}{l}\text { Desa } \\
\text { Pegayaman }\end{array}$ & $\begin{array}{l}\text { Waterfal } \\
l\end{array}$ \\
\hline $\begin{array}{l}31 \text { Banyuwana } \\
\text { Amerta } 3\end{array}$ & $\begin{array}{l}12,9 \\
\text { (Sedang) }\end{array}$ & $\begin{array}{l}8,3 \\
\text { (Lebar) }\end{array}$ & $\begin{array}{l}>70^{\circ} \\
\text { (Vertikal) }\end{array}$ & 914 & Desa Wanagiri & $\begin{array}{l}\text { Waterfal } \\
l\end{array}$ \\
\hline
\end{tabular}

Secara umum tipe air terjun yang terdapat di Kecamatan Sukasada didominasi oleh tipe cascade atau berundak-undak sekitar 25,8 \% atau sebanyak 8 air terjun, tipe waterfall sebanyak 6 air terjun, tipe parallel sebanyak 5 air terjun, tipe slide sebanyak 4 air terjun, tipe birai menggantung (Over hanging ledge falls) sebanyak 4 air terjun, dan tipe yang paling sedikit adalah tipe cataract sekitar 6,45\% atau 2 air terjun, dan tipe chute sekitar 6,45\% atau 2 air terjun. Dominasi tipe air terjun cascade yang memiliki bentuk berundak-berundak dipengaruhi 
oleh kondisi topografi aliran sungai di Kecamatan Sukasada yang berundak-undak dan dinding tebing air terjun yang memiliki bongkahan batuan yang tidak rata sehingga memiliki banyak jatuhan air terjun. Sedangkan untuk tipe air terjun yang memiliki jumlah yang sedikit yaitu tipe cataract dan chute, untuk tipe air terjun cataract memiliki karakteristik air terjun yang tinggi lebih dari 30 meter dan sebaran air terjun tipe ini terdapat di daerah Desa Wanagiri yang merupakan daerah hulu sungai dan air terjun tersebut merupakan sumber air atau hulu sungai yang berasal dari atas tebing. Kemudian untuk tipe chute memiliki karakteristik air terjun yang aliran airnya diapit oleh 2 dinding tebing di atasnya, umumnya air terjun ini terletak pada daerah patahan yang memiliki tingkat kecuraman tebing sungai yang tinggi pada aliran sungai.

Sebaran karakteristik air terjun di Kecamatan Sukasada memiliki variasi tipe yang menyesuaikan dengan kenampakan fisik wilayah lokasi air terjun tersebut. Sebagian besar wilayah Sukasada memiliki topografi perbukitan dan sebaran air terjunpun bervariasi ada yang mengelompok dalam satu lokasi, dan ada juga yang menyebar. Sehingga untuk memudahkan dalam melihat sebaran ataupun lokasi keberadaan air terjun dengan karakteristik yang khas maka akan disajikan dalam peta. Untuk lebih jelasnya dapat dilihat pada Gambar 1.

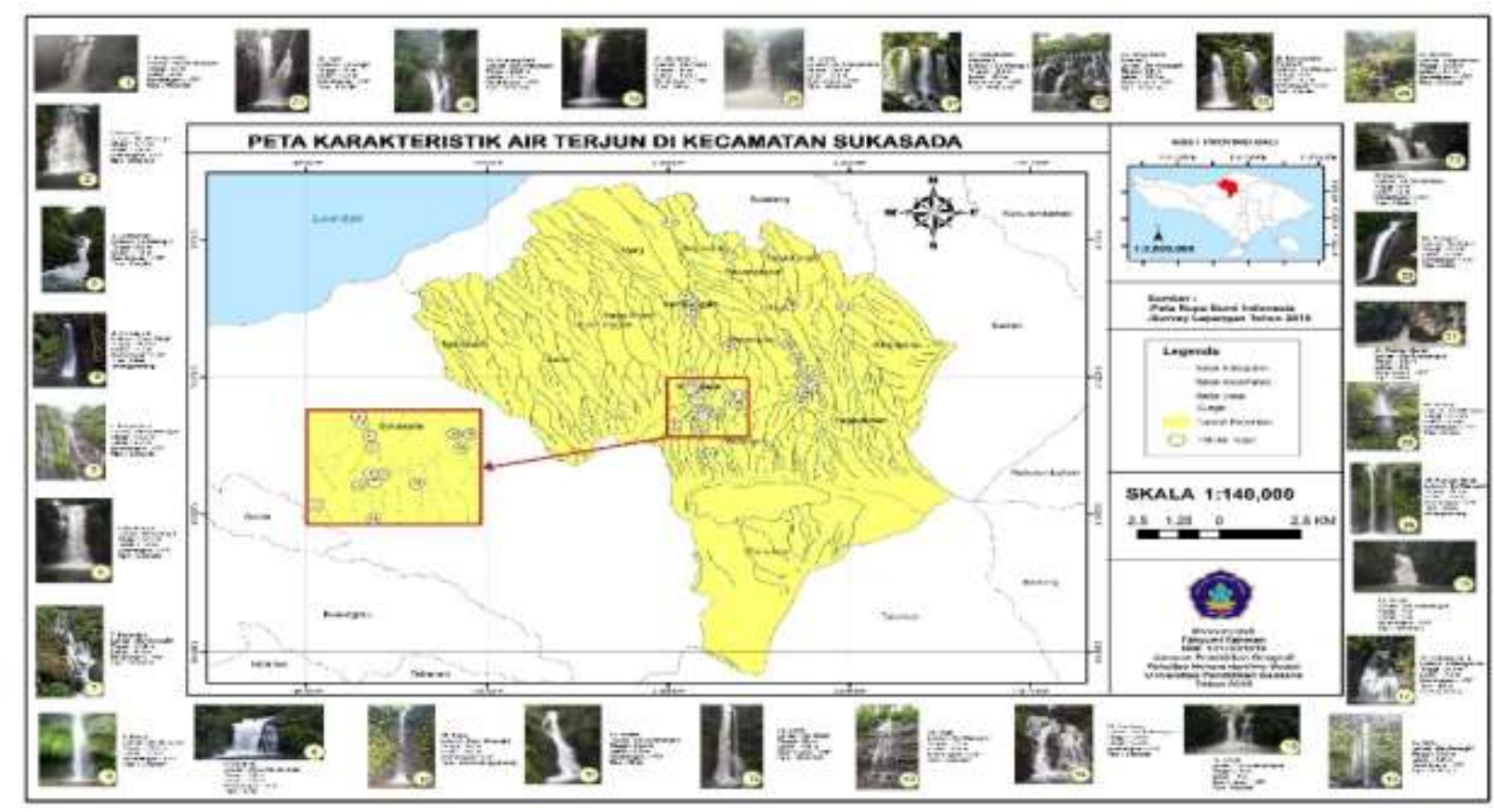

Gambar 1. Peta Karakteristik Tipe Air Terjun di Kecamatan Sukasada

\subsection{Tingkat Potensi Wisata Air terjun di Kecamatan Sukasada}

Pengukuran tingkat potensi wisata dilakukan dengan cara survei lapangan berdasarkan nilai penskoran pada variabel potensi wisata air terjun yang ditemukan di lapangan. Klasifikasi variabel menggunakan perhitungan jumlah skor minimum dan skor maksimum dari tiap skor variabel sehingga diperoleh interval kelas untuk mengkategorikan tingkat potensi wisata yaitu tingkat potensi wisata tinggi, tingkat potensi wisata sedang, tingkat potensi wisata rendah. Kategori tersebut diukur berdasarkan variabel atraksi wisata; panorama alam, tracking, olahraga ekstream, Akomodasi; pondok wisata, cinderamata, penginapan, aksesibilitas; jarak tempuh, waktu tempuh, kondisi jalan, Kelembagaan; pengelola dan ketersediaan kantor pengelola. Penskoran variabel dilakukan dengan nilai kategori tinggi 3, nilai kategori sedang 2, 
dan nilai kategori rendah 1 dalam menentukan akumulasi tingkat potensi wisata pada setiap objek wisata air terjun di Kecamatan Sukasada. Untuk lebih jelasnya dapat dilihat pada Gambar 2.

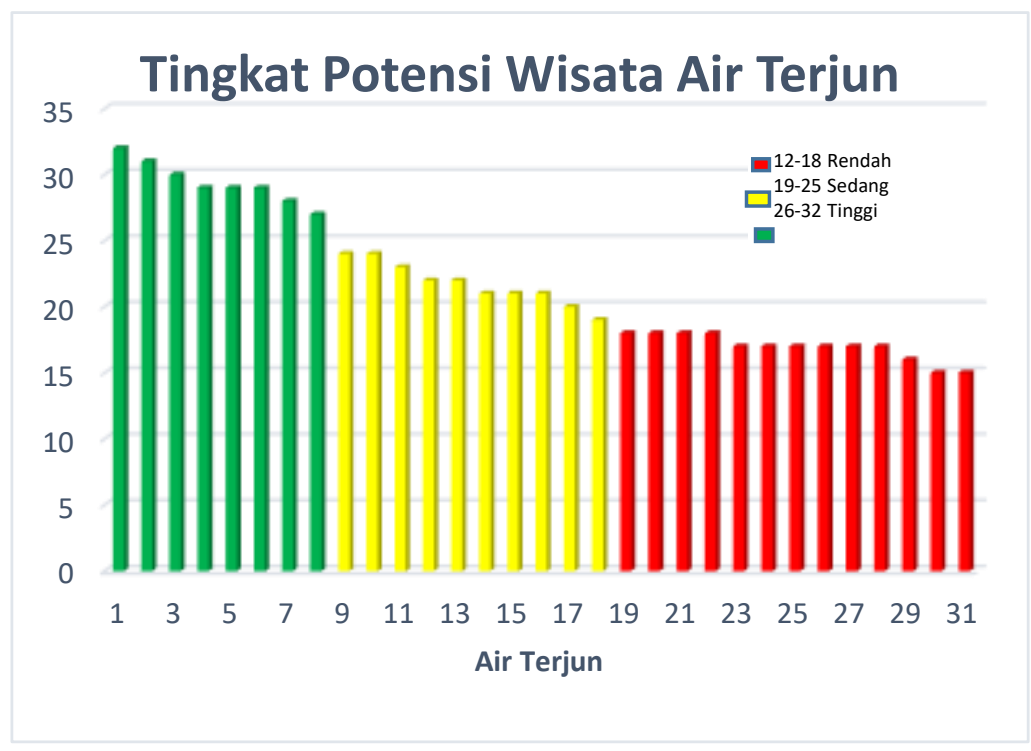

Gambar 02. Grafik Tingkat Potensi Wisata Air Terjun di Kecamatan Sukasada

$\begin{array}{ll}1=\text { Gitgit } & 17=\text { Indah } \\ 2=\text { Aling aling } & 18=\text { BWA } 3 \\ 3=\text { Twin Gitgit } & 19=\text { Tebing } \\ 4=\text { Kroya } & 20=\text { Berundak } \\ 5=\text { Tunggal } & 21=\text { Besar } \\ 6=\text { Jembong } & 22=\text { Padang Bulia } \\ 7=\text { Kembar } & 23=\text { Tembok barak } \\ 8=\text { Bertingkat } & 24=\text { Cemara } \\ 9=\text { Pucuk } & 25=\text { Campuhan } \\ 10=\text { Banyumala } & 26=\text { Merebo } \\ 11=\text { Cinta } & 27=\text { No Name } 1 \\ 12=\text { Puncak Manik } & 28=\text { Gunung sari } \\ 13=\text { BWA } 1 & 29=\text { No Name } 2 \\ 14=\text { Canging } & 30=\text { Cinon } \\ 15=\text { Dedari } & 31=\text { Neru } \\ 16=\text { BWA } 2 & \end{array}$

Berdasarkan Gambar 1 tingkat potensi di Kecamatan Sukasada terdapat perbedaan, variasi potensi diklasifikasikan menjadi Potensi wisata rendah, Potensi wisata sedang, potensi wisata tinggi. Kategorisasi tersebut disesuaikan dengan kenampakan daya tarik wisata dan fasilitas penunjang pariwisata, seperti halnya diungkapkan oleh Soekadijo (2000) bahwa antara motif wisata dan atraksi wisata harus ada kesesuaian atau komplementaritas, karena wisatawan selama melakukan kegiatan pariwisata tetap mempunyai kebutuhan-kebutuhan hidup biasa. Sehingga objek wisata yang memiliki tingkat potensi yang tinggi adalah yang dapat memenuhi 
kebutuhan-kebutuhan wisatawan (tourist needs), seperti jasa wisata, akomodasi, akses yang mudah, dan pramuwisata. Adapun kategorisasi tingkat wisata air terjun yang terdapat di Kecamatan Sukasada adalah sebagai berikut :

\section{Tingkat Potensi Wisata air terjun kategori tinggi}

Ada 8 air terjun atau $25.8 \%$ yang masuk kategori tingkat wisata tinggi yang tersebar di Kecamatan Sukasada yaitu diantaranya karakteristik tipe waterfall (Air Terjun Aling-aling, Gitgit), tipe cascade (Air Terjun Jembong, Kroya), tipe parallel (Air Terjun Kembar, Twin Gitgit), tipe slide (Air Terjun Tunggal). Adapun faktor yang mempengaruhi tingkat potensi wisata air terjun kategori tinggi yaitu atraksi wisata; Panorama alam yang bagus, kegiatan tracking yang bervariasi, dan adanya variasi olahraga ekstream yang menunjang kegiatan pariwsata, Dari segi akomodasi seperti pondok wisata, cinderamata, penginapan sudah tersedia dan menarik minat wisatawan untuk berkunjung, kemudian dari segi aksesibilitas; waktu tempuh yang umumnya tidak lebih dari 1 jam, jarak kurang dari $1 \mathrm{KM}$ dan kondisi aspal yang memudahkan akses, dan dari aspek kelembagaan; keaktifan pengelola dalam mengembangkan wisata air terjun, serta ditunjang dengan ketersediaan kantor pengelola sehingga akan mempengaruhi kemudahan wisatawan dalam mencari informasi tentang objek wisata air terjun. Potensi wisata air terjun dengan kategori tinggi umumnya berada dekat dengan akses jalan utama seperti air terjun Gitgit, Bertingkat dan Twin serta ditunjang dengan fasilitas pariwisata yang baik sehingga dapat menarik minat wisatawan untuk berkunjung dan melakukan kegiatan pariwisata.

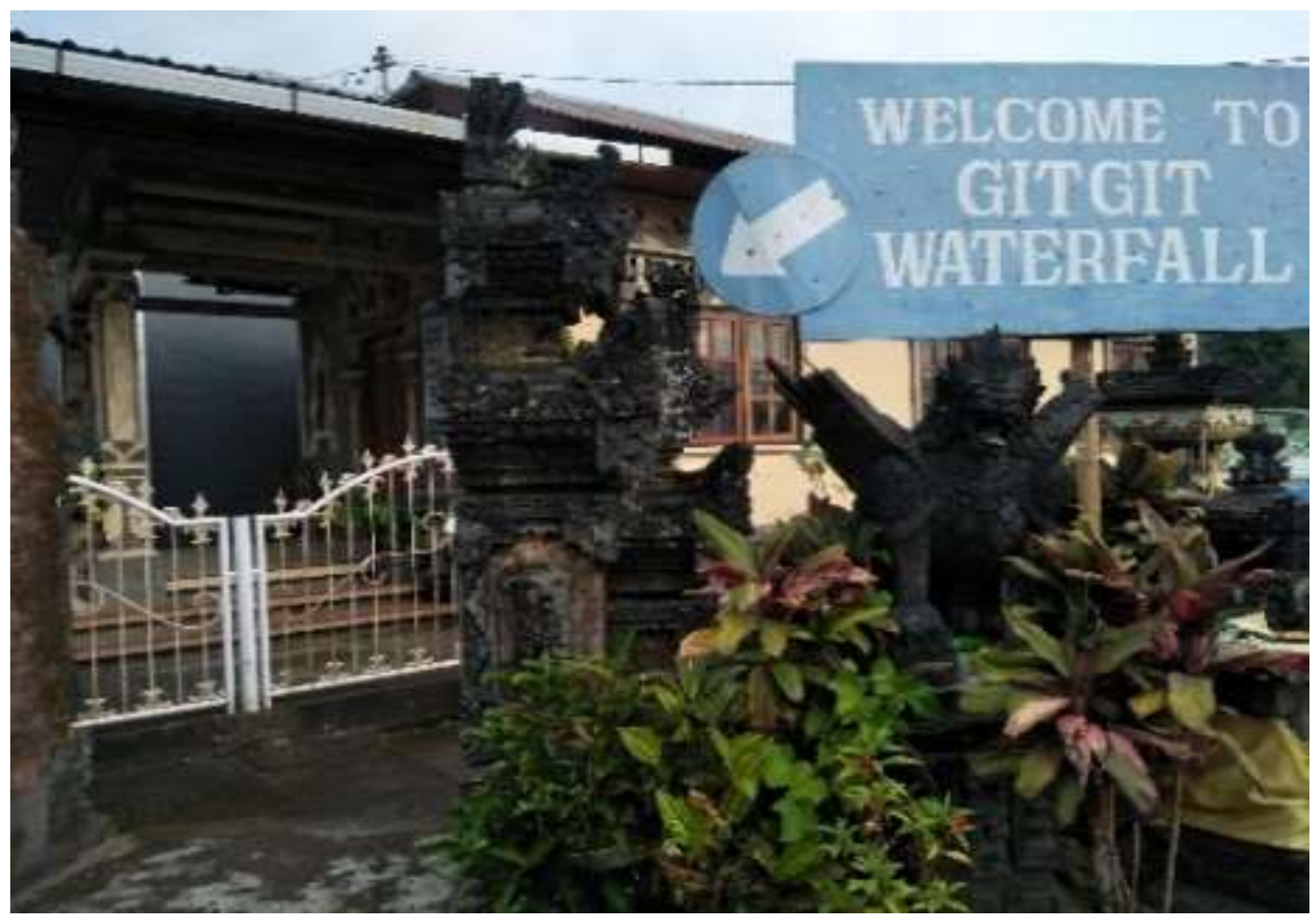

Gambar 3. Akses Jalan Air Terjun Gitgit

\section{Tingkat Potensi Wisata air terjun kategori sedang}

Ada 10 air terjun atau 32,25 \% yang masuk kategori tingkat wisata sedang yang tersebar di Kecamatan Sukasada yaitu diantaranya karakteristik tipe cascade (Air Terjun Banyumala, 
Banyuwana Amerta1, Indah), tipe waterfall (Air Terjun Pucuk, Banyuwana Amerta 3), tipe birai menggantung (Air Terjun Cinta, Puncak Manik), tipe slide (Air Terjun Canging, Dedari), tipe parallel (Air Terjun Banyuwana Amerta 2). Adapun faktor yang mempengaruhi tingkat potensi wisata air terjun kategori sedang yaitu atraksi wisata; Panorama alam, kegiatan tracking, dan olahraga ekstream yang masih belum tersedia untuk menarik minat wisatawan, akomodasi seperti pondok wisata, cinderamata, penginapan masih belum tersedia dan beberapa tersedia namun terbatas tidak lebih dari satu, kemudian dari segi aksesibilitas; waktu tempuh yang umumnya tidak lebih dari 1 jam, jarak kurang dari $1 \mathrm{KM}$ dan kondisi jalan tanah yang sedikit ekstream, dan Kelembagaan; adanya pengelola namun masih belum solid dalam mengembangkan wisata air terjun, serta tidak tersedianya kantor pengelola sehingga akan mempengaruhi kemudahan wisatawan dalam mencari informasi tentang objek wisata air terjun. Umumnya potensi wisata air terjun dari segi panorama alam sudah sangat baik hanya saja kurangnya pengembangan atraksi dan akomodasi pariwisata yang menarik minat wisatawan.

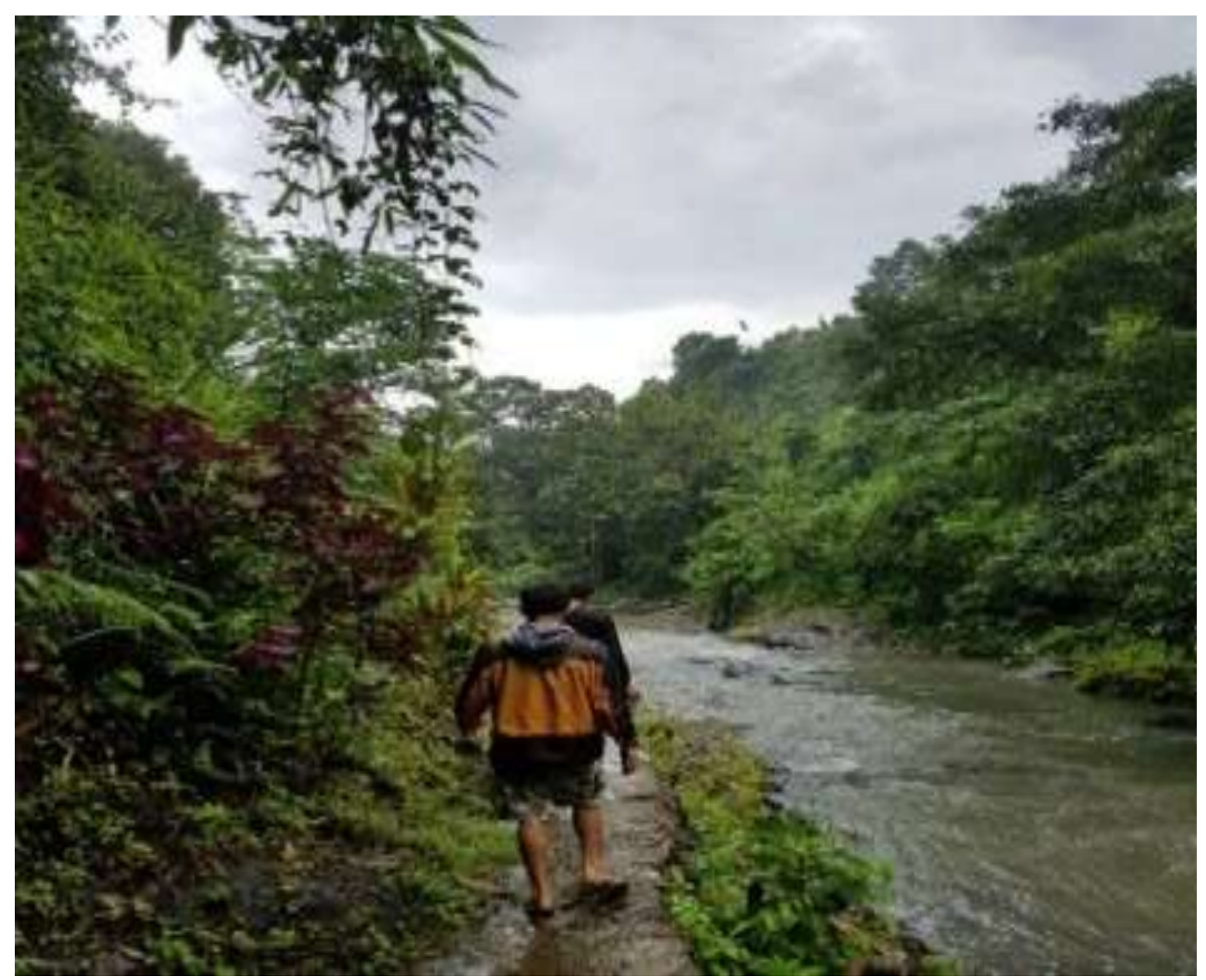

Gambar 04. Akses Jalan Air Terjun Pucuk

\section{Tingkat Potensi Wisata Kategori rendah}

Terdapat 13 air terjun atau 41,93 \% yang masuk kategori rendah yaitu diantaranya pada tipe cascade (Air Terjun Berundak, Gunung sari, Merebo), tipe cataract (Air Terjun Besar, dan Neru), tipe chute (Air Terjun Tembok Barak dan Tebing), tipe birai menggantung (Air Terjun Padang Bulia dan No name 2), tipe parallel (Air Terjun Campuhan Wanagiri), tipe slide (Air 
Terjun No name 1). Beberapa faktor yang mempengaruhi rendahnya tingkat potensi wisata air terjun yaitu atraksi wisata; seperti kegiatan tracking, olahraga ekstream; sebagai daya tarik wisatawan, akomodasi seperti pondok wisata, cinderamata, penginapan masih belum tersedia, kemudian dari segi aksesibilitas; waktu tempuh yang lama, jarak dan kondisi jalan tanah yang ekstream sulit ditempuh serta beberapa air terjun tidak memiliki akses dan mengharuskan untuk membuka jalur menuju air terjun, dan Kelembagaan; tidak adanya pengelola dan kantor pengelola sehingga mengakibatkan kurang terkelolanya objek wisata air terjun. Umumnya potensi wisata air terjun dari segi panorama alam sudah sangat baik hanya saja akses keterjangkauan yang sulit dan belum dikelolanya objek wisata air terjun tersebut.

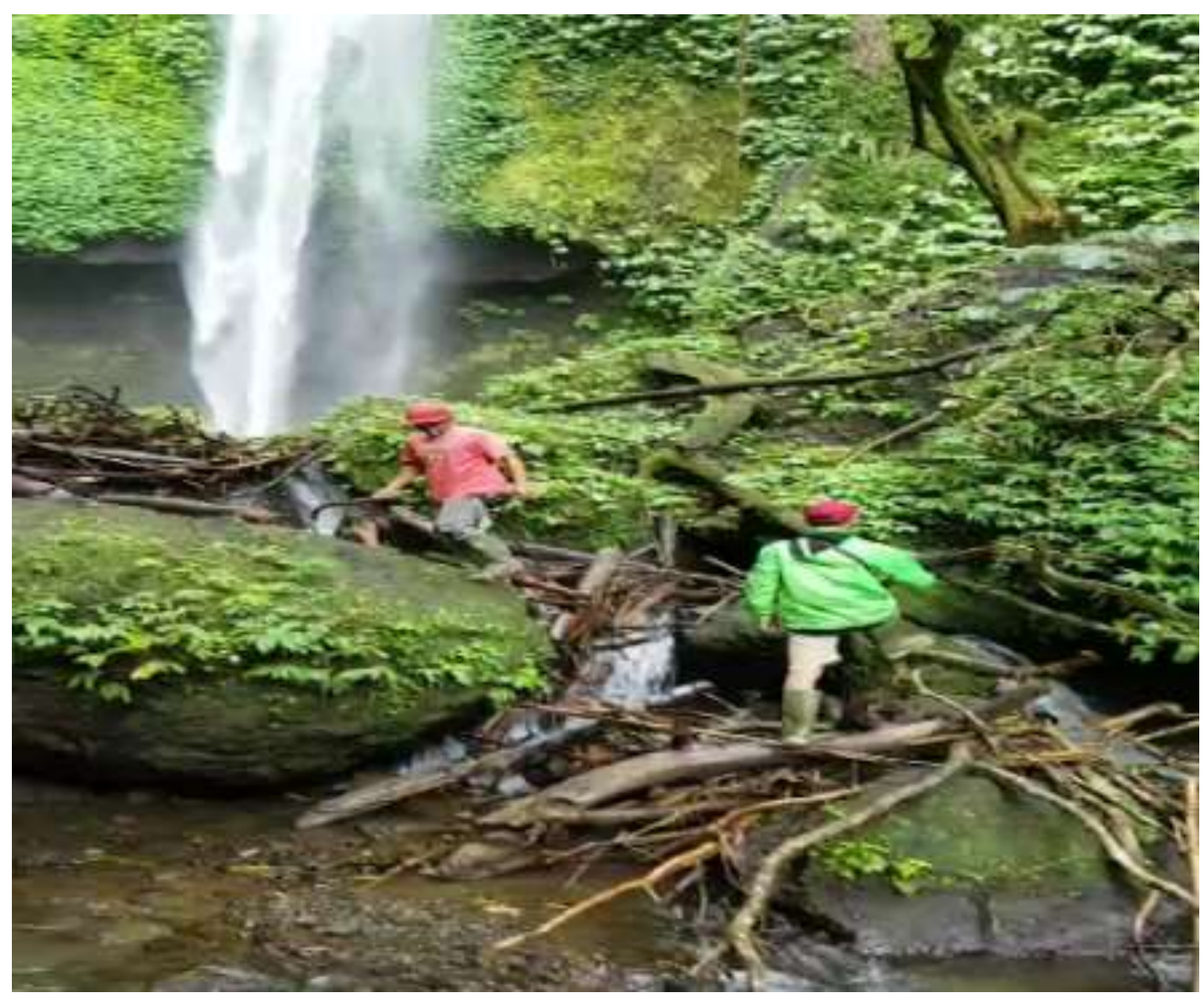

Gambar 5. Akses Jalan Air Terjun Besar

Selain itu pengembangan pariwisata Bali juga arus disesuaikan dengan daya dukung yang dimiliki dan menetapkan sistem pembangunan kepariwisataan yang berkelanjutan agar lingkungan yang menjadi daya tarik utama dapat terjaga kelestariannya (Citra, 2015).

\section{Simpulan dan saran}

Berdasarkan hasil penelitian dan pembahasan penelitian ini yang terkait dengan karakteristik dan tingkat potensi wisata alam air terjun, dapat disimpulkan sebagai berikut. Kecamatan Sukasada memiliki tujuh karakteristik air terjun yaitu diantaranya tipe cascade, tipe cataract, tipe chute, tipe slide, tipe over hanging ledge falls atau birai menggantung, tipe parallel 
atau twin, tipe waterfall. Air terjun dengan tipe cascade adalah paling banyak terdapat di Kecamatan Sukasada, berada pada kondisi topografi aliran sungai yang berundak-undak dan dinding tebing air terjun memiliki bongkahan batuan yang tidak rata dan memiliki banyak jatuhan air terjun. Sedangkan untuk tipe air terjun yang memiliki jumlah yang sedikit yaitu tipe cataract dan chute, untuk tipe air terjun cataract memiliki karakteristik air terjun yang tinggi lebih dari 30 meter dan sebaran air terjun tipe ini terdapat di daerah daerah hulu sungai dan air terjun tersebut merupakan terbentuk dari sumber air yang berasal dari atas tebing. Kemudian untuk tipe chute memiliki karakteristik air terjun yang diapit oleh 2 dinding tebing, umumnya air terjun ini terletak pada daerah patahan yang memiliki tingkat kecuraman tebing sungai tinggi yang dilalui aliran sungai. Air terjun yang terdapat di Kecamatan Sukasada memiliki tingkatan potensi yang berbeda-beda yang diklasifikasikan menjadi tiga kategori, yaitu kategori tinggi, sedang, dan rendah. Air terjun yang memiliki tingkat potensi tinggi hanya sekitar 25,8 \% dengan karakteristik tipe waterfall, parallel, slide, cascade umumnya memiliki variasi atraksi wisata yang baik, akomodasi dan aksesibilitas yang mudah dijangkau dan sebagian besar dekat dengan jalan utama. Tingkat potensi wisata kategori sedang terdapat 32,25\%, dengan karakteristik tipe cascade, birai menggantung, slide, waterfall, parallel, beberapa faktor yang mempengaruhi yaitu akomodasi wisata yang belum maksimal serta variasi atraksi wisata yang belum beragam. Sedangkan untuk tingkat potensi air terjun dengan kategori rendah adalah yang terbanyak yaitu sekitar 41,93\% dengan karakteristik tipe waterfall, cascade, cataract, chute, birai menggantung, parallel. Faktor dominan mempengaruhi rendahnya tingkat potensi wisata air terjun tersebut diantaranya belum terbukanya akses menuju air terjun, atraksi dan akomodasi yang belum memadai bahkan tidak ada, serta pengelolaan objek wisata yang belum maksimal.

Berdasarkan kesimpulan di atas, maka terdapat beberapa saran sebagai berikut. Bagi Dinas Pariwisata, diharapkan bisa ikut mengambil andil dalam meningkatkan potensi wisata alam air terjun di Kecamatan Sukasada dalam hal anggaran pengembangan, pemeliharaan dan pembinaan kelompok sadar wisata dari elemen masyarakat, mengingat hasil dari penelitian ini bahwa terdapat 13 air terjun atau sekitar 41,93 \% yang masih belum maksimal dalam pengelolaannya. Selain itu optimalisasi potensi wisata alam air terjun dibutuhkan kolaborasi dari pemerintah daerah, akademisi dan masyarakat untuk mencapai pembangunan kepariwisataan yang komprehensif. Bagi pengelola objek wisata alam air terjun, hendaknya memperhatikan karakteristik bentuk air terjun yang terdapat di Kecamatan Sukasada sebagai acuan dalam mengembangkan model atraksi wisata yang efisien pada tipe air terjun tertentu. Selain itu variasi tipe air terjun yang terdapat di Kecamatan Sukasada hendaknya disebarluaskan sebagai sarana informasi terkait karakteristik dan potensi wisata air terjun bagi wisatawan. Bagi masyarakat yang bertempat tinggal pada daerah tangkapan hujan atau pada daerah hulu sungai agar tetap menjaga kelestarian vegetasi dengan cara tidak melakukan deforestasi dan dibuatkan regulasi untuk menjaga kontiunitas debit aliran air sungai dan eksistensi wisata alam air terjun yang tersebar di Kecamatan Sukasada.

\section{Daftar Rujukan}

Citra, I. P. A. (2015). Studi Kelayakan Potensi Objek Wisata Alam Untuk Pengembangan Ekowisata Di Kabupaten Buleleng. Media Komunikasi Geografi, 16(2).

Lobeck, A. . (1981). Geomorfologi : Pengenalan kepada kajian pandangan darat. Kuala Lumpur: Percetakan Dewan Bahasa dan Pustaka.

Lubis, N. L. (2011). Memahami Dasar-dasar Konseling dalam Teori dan Praktek. Jakarta: Kencana. Marjohan, A. (2008). Karakteristik Fisik Air Terjun di Cagar Biosfer Gunung Gede Pangrango. 
Indonesia.

Pitana, I G dan Diarta, I. K. S. (2009). Pengantar Ilmu Pariwisata. Yogyakarta: C.V Andi Offset. Soekadijo, R. . (2000). Anatomi Pariwisata. Jakarta: PT Gramedia Pustaka Utama.

Suditha, I Nyoman dan Astawa, I. B. M. (2013). Pengantar Geografi Regional. Singaraja-Bali: Undiksha press.

Sutrisno. (2016). Predisposisi Partisipasi Masyarakat dalam Perencanaan Kampung Wisata. Agribisnis, 2(1).

Tika, M. P. (2005). Metode Penelitian Geografi. Jakarta: PT. Bumi Aksara.

Yunus, S. H. (2016). Metodologi Penelitian Wilayah Kontemporer. Yogyakarta: Pustaka Pelajar. 